\title{
Türkiye'nin Mevcut İç Güvenlik Yapısı ve 15 Temmuz Sonrası Yeni Bir Yapılanma Modeli
}

\section{Turkey's Current Structure of Internal Security and A New Construction}

Model After July 15

\section{Doç. Dr. Mehmet Ali Tekiner ${ }^{1}$}

Öğr. Gör. Eser Gemici²

Başvuru Tarihi: 14.10 .2019

Kabul Tarihi: 03.12.2019

Öz

Insanların en temel ihtiyaçlarından biri olan güvenlik ihtiyacı, yine aynı bireylerin bir araya gelerek meydana getirdikleri örgütsel bir yapı olan devletin yerine getirmesi gereken temel işlevlerinden biri haline gelmiştir. Çünkü toplumdaki bireyler sadece kendi güvenliğinden değil diğer bireylerin de güvenliğinden emin olmak isterler. Devlet ilgili tüm bu ihtiyaçları giderirken sadece dış güvenliğe ilişkin hususları dikkate almaz aynı zamanda iç güvenliği de sağlayarak toplumun güvenli bir ortamda huzurlu ve rahat bir şekilde yaşamasına olanak sağlar. Bu anlamda iç güvenliğe ilişkin gündelik hayattaki tüm unsurlar ve ayn zamanda kamu düzeninin korunması hususu polis, jandarma ve sahil güvenlik komutanlı̆̆ı aracıllğı ile yerine getirilir.

Bu çalışmada, 15 Temmuz'a kadar olan süreçte Türkiye'nin sahip olduğu iç güvenlik yapısı ve kolluk kuvvetlerinin karşılaştı̆̆ sorunlar ele alınmıştır. Diğer yandan farklı ülkelerdeki iç güvenlik yapısı incelenmiş ve bu anlamda karşılaştırmalar yapılmıştır.Tüm bu verilerden yararlanılarak, Türkiye'nin iç güvenlik birimlerinin yapısına ilişkin bir tablo oluşturulmaya çalışılmıştır.Farklı kurumlara bağlı kolluk kuvvetleri arasındaki gerek istihbarat paylaşımı gerek eğitim gerekse devletin kritik noktaları olması bakımından belli grupların hedefi haline gelmesihususları irdelenmiştir. Tüm bu nedenlerle bu makalede, 15 Temmuz tecrübesi ve Cumhurbaşkanlığı sisteminin ardından Türkiye'nin iç güvenlik yapısında yeni bir yapılanmanın hayata geçirilmesinin Türkiye’nin iç güvenliğinin güçlü ve daha etkin hale gelmesi bakımlarından yararlı olacă̆ı değerlendirilmektedir.

Anahtar Kelimeler: s.Güvenlik, İç Güvenlik, Polis, Kamu Düzeni, Yeni Yapılanma Modeli

\footnotetext{
${ }^{1}$ Polis Akademisi Başkanlığı, malitekiner@gmail.com, ORCID ID: 0000-0002-3261-5777

2 Anadolu Üniversitesi İ̉BF, esergemici@gmail.com, ORCID ID: 0000000289693151
} 


\begin{abstract}
The security one of the most basic needs of peoplehas become one of the basic functions that the state must fulfill as an organizational structure that brings together the same individuals.Because the individuals in society want to be sure not only their own safety but also the safety of other individuals. While fulfilling all these needs, the government not only takes into account the issues related to external security but also provides internal security, enabling the society to live in a safe and secure environment. In this sense, all elements of daily life in relation to internal security, as well as the protection of public order, are fulfilled by the police, gendarmerie and coast guard command.
\end{abstract}

In this study, the internal security structure that Turkey had in the process up to 15 July and the problems that the law enforcement agencies encountered were analyzed. On the other hand, the internal security structures in different countries were examined and compared in this sense. By using all these data, an attempt was made to create a table about the structure Turkey's internal security units. It has been examined that The sharing of intelligence between the law enforcement officers of different institutions and their education and the law enforcement officers become the targets of certain groups in terms of being the critical points of the state. For all these reasons, it is evaluated that following the July 15's experience and Presidency system, creating a new structure on Turkey's internal security will be beneficial for Turkey's internal security to become stronger and more effective.

Keywords: s.Security, Internal Security, Police, Public Order, New Structuring Model

\title{
Giriş
}

Günümüzde tehdit, her zaman ve her yerde ortaya çıkabilmekte olup herhangi bir sınır veya cephe kavramınasahip değildir. Geleneksel terörizmdeki hiyerarşik yapılar küresel terörizmde yerini, belirli bir liderlik mekanizması olmayan ve belirli bir merkezi bulunmayan yapılara bıraktığı gibi yeni terörizm amacının, metodunun ve örgütsel yapısının farklılaştığ 1 görülmektedir (Crenshaw, 2000, s.411). Ancak bu noktada şunu da belirtmek gerekir ki, her ülkenin kendine özgüçevresel, coğrafi, ekonomik, politik vb. koşulları ve gereksinimleri bulunmaktadır. İç güvenlikte yeniden yapılanmaküresel değişimler bir yana, o ülkenin kendi geçmişinin, kültürünün, sosyal ve siyasal yapısının ve daha pek çok farklı unsurunun bu yapılanma üzerinde belirleyici etkilerinin olacağının da göz ardı edilmemesi gerektiği ifade edilmektedir (Yılmaz, 2011, s. 362-363).

Türkiye'deki iç güvenlik yapılanmasına bakıldığında ise 1947'deki başarısız Güvenlik Müsteşarlığı denemesi (Resmi Gazete, 18.06.1947) ve 80'li yıllarda Sahil Güvenlik Komutanlığı'nın doğrudan İçişleri Bakanlığı’na bağlanması (Resmi Gazete, 23.02.1985) dışında, 15 Temmuz sonrasına kadarciddi sayılabilecek bir örgütsel yapılanma değişikliğinin 
ortaya konulmadığı anlaşılmaktadır. Burada anlatılmak istenen, İçişleri Bakanlığı çatısı altında bağlı kuruluşlar şeklinde yapılandırılan ülkenin iç güvenlik örgütsel yapılanmasıdır. 15 Temmuz sonrası gerek jandarmanın İç İşleri Bakanlığı'na bağlanması gerekse Cumhurbaşkanlığı sistemi ile birlikte Milli İstihbarat Teşkilatının Cumhurbaşkanlığına bağlanması ülkemizin iç güvenlik örgütlenmesinin yeniden yapılanmasına yönelik yeni adımların da geleceğinin habercisi olarak karşımıza çıkmaktadır.

Son yıllarda Türkiye'nin İç Güvenlik Yapılanması alanındaki değişim girişimlerine ilişkin bu çalışmanın, bir yandan bu alanda atılan adımların başarısına ışık tutması ve katkı sağlamasıumulurken, diğer yandan da 15 Temmuz sonrası ve Cumhurbaşkanlığı sisteminin ortaya çıkışı ile birlikteliteratürde bu alanda yaşanan önemli bir boşluğun doldurulmasına katkıda bulunması amaçlanmaktadır.Bu amaçla bu çalışmada, güvenlik, kamu düzeni ve iç güvenlik gibi kavramlara ilişkin literatür bilgisinin yanı sıra Türkiye'deki iç güvenlik yapılanması ile ilgili tüm birimler bir tablo halinde ortaya konulmaya çalışılmış ve ilgili alandayaşanan sorunlar ve değişim gereklerinden hareketle, bu değişim ihtiyacına cevapverecek,iç güvenlikte yeniden yapılanma girişimini başarıyaulaştıracak, değişim sürecinde etkinlik ve verimlilik sağlayacak, iç güvenlik alanındakimevcut örgütler ve çalışanları tarafından kabullenilecek vekurumsallaşarak kalıcılığının sürdürüleceği yeni biriç güvenlik yapılanma modeli ortaya konulmaya çalışılmıştır.

\section{Güvenlik, Kamu Düzeni, İç Güvenlik Kavramları ve Türkiye'nin Mevcut İç Güvenlik Yapısı (Kavramsal İnceleme ve Literatür Araştırması)}

\section{Güvenlik Kavramı}

Güvenlik kavramı, zihnin felsefi ve psikolojik durumunu ifade eden şekliyle ilk olarak Cicero ve Lucretius tarafından "securitas" olarak ortaya konulmuştur (Brauch, 2003, s. 52). Cabric (2015), güvenlik kelimesinin sözel kaynağının ve anlamının analizinden önce onun özünü anlamanın daha faydalı olacağını dile getirmekte ve en eski atalarımızdan beri güvenliğin ilkelerinin değişmediği ifade etmektedir. Bu anlamda, bir mağara adamının, başkaları ortaya çıabilecek herhangi bir tehlike durumunda önceden herkesi uyarabilmek için gözetleme yaparken mağarasını bir mızrak ile korumakta olduğunu ve toplumdaki herkesin tehlikeli bir durumda neler yapmaları gerektiğini bildiklerini belirtmektedir. Buradan hareketle mağarayı güvenliğin fiziksel, tüm toplum üyelerini ise hem insan hem de süreç elementi, mızrağı teknoloji, yakın ve yaklaşan tehlikenin farkındalığını bilgi, toplum üyeleri arasındaki haber alışverişini iletişim, toplum liderini yönetici olarak sayarak güvenliğe ilişkin yedi (7) önemli temel sütun ortaya koymaktadır. Bu sütunların herhangi birinin yokluğu durumunda sistemin çalışmayacağını belirtmektedir. Bu sütunlar ise şöyle sıralanmaktadır (Cabric, 2015, s. 3);

- Fiziksel

- Teknik (Teknolojik)

- İnsan 
- Bilgi

- İletişim

- Süreç

- Yönetim (Kontrol)

Modern güvenlik kavramının ise iç güvenliğin, dış ve askeri politikaların ve uluslararası hukukun temel bir unsuru olan diş güvenlikten ayrılmaya başladığı 17. yüzyıldan bu yana geliştiği aktarılmaktadır (Brauch, 2008, s. 3; Rothschild, 2007, s. 6).

Güvenlik kavramının, literatürde özünde ihtilaflı bir kavram olarak tanımının ortaya konmasının mümkün olmadığı (Çıtak, 2014, s. 42) veya tüm zamanlar ve mekanlar için geçerli bir cevabının bulunmadığı (Şöhret, 2014, s. 658) ya da esasen basit bir kavram olduğu ve bu anlamda tanımının açık olduğu dile getirilmektedir (Booth, 2007, s. 126-127). Güvenlik, kelime anlamı olarak en basit ifadeyle tehditler, kaygılar ve tehlikelerden uzak olma hissi içerisinde bulunma hali olarak tanımlanmaktadır (Çalık, 2014, s. 638).Buradan hareketle güvenlik, bir bireyin diğerlerinin verebileceği zararlardan ya da tehlikeli ihtimallerden uzak olduğunu düşündügü, hissettiği ruh hali olarak açıklanmaktadır (Brauch, 2008, s. 5). Diğer yandan tehditlerin, tehlikelerin, zararlı olasılıkların yokluğubiçiminde tarif edilen güvenliğin(Booth, 1991, s. 319), öznenin varlığı (biri ya da bir şeyin tehdit altında olması); yaklaşan ya da fiili bir tehlike; tehlikeli ihtimallerden kaçmak için bir isteğin bulunması, şeklinde üç temel bileşenden oluştuğu ifade edilmektedir.Tüm bu bileşenler dikkate alındığında hangi öznenin, hangi tehlikeye karşı hangi öncelikte olacağı sorunu ile karşılaşılmakta ve Booth (2007) güvenliğin bu anlamda tanımının basit olduğunu ancakdünya siyaseti bağlamında güvenlik kavramına ilişkin tanımın kavramın anlamında olmayıp anlamın siyasetinde olduğunu dile getirmektedir. Çünkü güvenlik kelimesinin siyasal söylemde öncelik ifade ettiğini ve siyasi söylem ile güvenlikten ne anlaşılması gerektiği dile getirildiği an, toplum tüm zaman, enerji ve kaynaklarını ilgili siyasi söylemin ortaya koyduğu güvenlik anlayışına yönlendirmektedir (Booth, 2007, s. 127-128).

Güvenlik, korku veya tehlikelerden arınmış bir şekilde özgür ya da bu korku ve tehlikelere karşı savunma yeteneğine sahip olmak şeklinde de tanımlanmaktadır(Brauch, 2003, s. 53; Waever, 2012, s. 1510). Buzan (1983) ise güvenliği, toplumun ve devletin sahip olduğu bağımsız kimliği ve bütünlüğü koruma hususundaki kabiliyet olarak tanımlamaktadır (Buzan, 1983, s. 18-19). Erdoğan (2013) çalışmasında güvenlik kavramının, tehlike, zarar veya korku gibi unsurlar ile karşı karşıya kalma ya da kalmama şeklinde bir edilgen, ilgili unsurların ortaya çıkmasına neden olan bir de etken boyutu olduğunu belirtmek suretiyle güvenliğe ilişkin tanımı ortaya koymaktadır. Edilgen boyutta, güvenliği sağlanması gereken süjelerin, etken boyutta ise bu süjelere yönelmiş tehditlerin neler olduğu sorusuna yanıt arandığını görmekteyiz. Ancak bu sorulara yanıt ararken güvenlik kavramına ilişkin olarak güvenilebilir ve süreklilik arz eden bir tanımın ortaya konulmasının küreselleşen dünyada zor olduğunu ifade etmektedir (Erdoğan, 2013, s. 270). 
Geçmişten günümüze tartışıla gelen güvenliğe ilişkin tüm bu tanımlamalar ile birlikte Soğuk Savaş döneminin ortaya çıkardığı yapay korkular üzerine inşa edilen geleneksel güvenlik telakkisinin son yıllarda devletlerin birbirlerine bağımlılı̆̆ ve küreselleşmenin tesiri ile yerini gerçek korkulara ve yeni güvenlik alanlarına bıraktığ ifade edilmektedir (Şöhret, 2014, s. 659). Bu anlamda yeni dönemde çevre güvenliği, ekonomik güvenlik, siyasi güvenlik, toplumsal güvenlik, bilgi güvenliği ve birey güvenliği vb. gibi yeni güvenlik alanlarının, unsurlarının ortaya çıktığı görülmektedir (Waever, 2014, s. 49).

Son olarak güvenlik kavramı hususunda literatürde yapılan tüm tanımlamalardan güvenlik kavramına ilişkin olarak belirgin özelliklerin şu hususlar olduğu dikkat çekmektedir (Öksüz, 2006, s. 52);

- Tehlikeli bir durumun varlığı,

- Alınacak tedbir ve önlemleri,

- Asayiş ve huzurun sürekli hakim kılınması,

- Suç ve suçluluğun önlenmesi,

- Kamu gücünün meşru güç olarak kullanılması,

- Kamu düzenin sağlanması.

\section{Kamu Düzeni Kavramı}

Birbirine benzer tanımlamalar ile ortaya konulmaya çalışılan kamu düzeninin aslında ne olduğu hususunda tam bir fikir birliği bulunmamakla birlikte kamu düzeninin hem hukuk devletinin hem de toplumun güvenlik ve emniyet içerisinde yaşamasının, bireylerin kendi aralarındaki çıkarlarının temin edilmesi ile bireylerin devlet karşısında temel hak ve özgürlüklerinin sağlanmasının temeli olduğu ifade edilmektedir (Çinar, 2014, s. 5). Kamu düzeni, kamu ve düzen kelimelerinin bir arada kullanılması sonucu bir anlam içeren bir kavramdır. Kamu ve düzen kelimelerinin anlamsal içeriklerine ayrı ayrı bakıldığı takdirde; kamu bir ülke içerisindeki halkın tümü, amme ve toplum olarak ifade edilirken, düzen barış, huzur ve tertip anlamlarında kullanılmaktadır (Doğan, 2010, s. 12; TDK, Büyük Türkçe Sözlük; Üzel, 2008, s. 13). Kamu düzeni ise kavramsal olarak iç güvenliğin sağlanması anlamında kullanılması halinde kişilerin ve toplumun mevcut hukuk düzeninin ortaya koyduğu kurallara bağlı kalmak şartı ile sağlıklı ve barışık bir ortamda güvenlik ve refah içerisinde yaşayabilmeleri olarak ifade edilmektedir (Akyüz, 2015, s. 68; Odyakmaz, Kaymak ve Ercan, 2008, s. 478). Aynı zamanda idare hukukunun temel kavramlarından biri olarak gösterilen kamu düzeni, medeni bir toplumda fertlerin güvenlik, huzur ve sağlık içerisinde yaşamlarını sürdürmeleri durumu olarak da tanımlanmaktadır (Gözler, 2009, s. 473; Günday, 1997, s. 192). Günday (1997) kamu düzeninin, toplum içerisindeki bireylere ilişkin veya bireysel ya da özel çıkarlara dayalı bir düzen olmadığı aksine toplumun dış ve maddi yönüne ilişkin olarak yollar, parklar, meydanlar, kahvehaneler, tiyatro, sinema, han, hamam, otel, lokanta gibi umumi ve umuma açık yerlerde ortaya konulmuş bir düzen olduğu ifade edilmektedir (Günday, 1997, s. 192). İdari kolluk faaliyetlerinin temel amacı ve faaliyet alanı olarak gösterilen kamu düzeninin, bireylerin sahip oldukları ahlak anlayışına göre evlerinde, 
işyerlerinde, iç yaşantılarında oluşturdukları düzenin dışında olduğu belirtilmektedir (Günday, 1997, s. 192; Odyakmaz, Kaymak ve Ercan, 2008, s. 478).

Günday (1997) ve Gözler (2009) tarafından kamu düzeninin, kamu güvenliği, kamu huzuru (dirlik ve esenlik) ve genel sağlık olmak üzere üç unsurunun bulunduğu ifade edilirken (Gözler, 2009, s. 473; Günday, 1997, s. 192), Odyakmaz, Kaymak ve Ercan (2008) ortaya konulan çalışmada, kamu düzeninin bu üç unsurunun yanında bir de genel ahlak unsuruna sahip olduğu aktarılmaktadır (Odyakmaz, Kaymak ve Ercan, 2008, s. 478-480).

\section{İç Güvenlik Kavramı}

Güvenlik kavramına ilişkin tüm tanımlamalar ve yeni unsurlar dikkate alınarak iç güvenliğin kavramsal tanımı noktasındaki çalışmalara bakıldığında ise; iç güvenlik kavramının, bir ülke sınırları içerisindeki güvenliğe gönderme yaparak ve özellikle de terörle mücadele anlamında ilk defa 21. yüzyılda ABD Ulusal Güvenliği Hakkındaki Ulusal Komisyonun Raporu'nda geçtiği görülmektedir (Seiple, 2002, s. 260). İç güvenliğin,bir ülkenin coğrafi sınırları içerisinde olası tehdit ve tehlikelerden uzak bir ortamda öncelikle vatandaşlarının huzur ve güvenliğinin sağlanması, sonrasında ise devlete ve özel şahıslara ait mülkiyetin tüm sabotaj ve benzer nitelikteki tehlikelere karşı korunması şeklinde tanımlandığı görülmektedir (Çınar, 1997, s. 61). Kamu düzeni kavramının tanımı yapılırken de belirtildiği üzere iç güvenlik kavramı kamu düzeninin bir gereği olarak karşımıza çıkmaktadır (Üzel, 2008, s. 13).Bu sebeple, iç güvenlik kavramının geniş bir anlama ve kapsama sahip olduğu ve genel manada iç güvenlik; bir devletin kendi sınırları içinde yaşayan vatandaşlarına sağlamak zorunda olduğu kamu düzeninin yanı sıra vatandaşların kendilerini özgür hissedebildikleri, mutlu ve huzurlu olabildikleri bir ortama sahip oldukları aynı zamanda suçun önlenmesi ve suçluların yakalanması ile ilgili teşkilat ve hukuki rejimin bulunduğu bir yapı şeklinde tanımlandığı anlaşılmaktadır.

Seiple (2002), iç güvenlik kavramını, ülke sınırları içinde faaliyet gösteren geleneksel tarzdan uzak terör veya suç örgütü durumundaki bir düşmana karşı yurt savunmasına şeklinde tanımlamaktadır (Seiple, 2002, s. 267). Diğer bir tanımda Yılmaz (2012), iç güvenliğin, ülke sınırları içerisinde, vatandaşların can ve mal güvenliği ile bir bütün olarak toplumun sahip olduğu her türlü varlık, kazanım ve sistemler gibi yaşam kalitesi öğelerinin güvenliği için yürütülen faaliyetlerin tümünü kapsadığı ifade edilmektedir (Yılmaz, 2012, s. 8). Bir başka tanımda iç güvenlik; devletin, toplumun güvenlik ve özgürlük içerisinde yaşamını sürdürebilmesi amacıyla kanunlar vasıtasıyla ortaya koyduğu adli ve idari düzenlemelerin yine devlet tarafından yetkilendirilen kurumlarca korunması ve sürekliliğinin sağlanması şeklinde tanımlandığı görülmektedir (Çinar, 2014, s. 23).

11 Eylül 2001 tarihinde ABD’de gerçekleșen Dünya Ticaret Merkezi ve Pentagon terör saldırılarının ardından iç güvenlik (homeland security) kavramının tüm dünyada ülke savunması maksadıyla terörle mücadele ve terörden korunma anlamında yoğun bir şekilde kullanıldığı görülmektedir (Çinar, 2014, s. 23). Ancak bu unsurların yanı sıra iç güvenliğin, 
deprem, sel, tayfun gibi doğal felaketler ile insan ürünü olan ve iç güvenliği tehdit eden kimyasal patlamalar gibi olaylar karşısında alınan tedbirleri ve yürütülen faaliyetleri de kapsadığı ifade edilmektedir (Sauter ve Carafano, 2005'ten akt. Yılmaz, 2011a, s. 364). İç güvenlik kavramının,gerek terör gerekse doğal ve insan faaliyetleri sonucu oluşabilecek tehlikelere karşı alınacak önlemlerin tümünü içerir bir şekilde düşünülmesi gerektiği anlaşılmaktadır. Bu bağlamda Bellavita (2008), iç güvenlik denilince ne anlaşılması gerektiğini bütüncül bir yaklaşım ile belirtmek adına iç güvenliğe ilişkin olarak, aşağıdaki şekilde de görüldügü gibi, yedi (7) tanım ortaya koymaktadır.

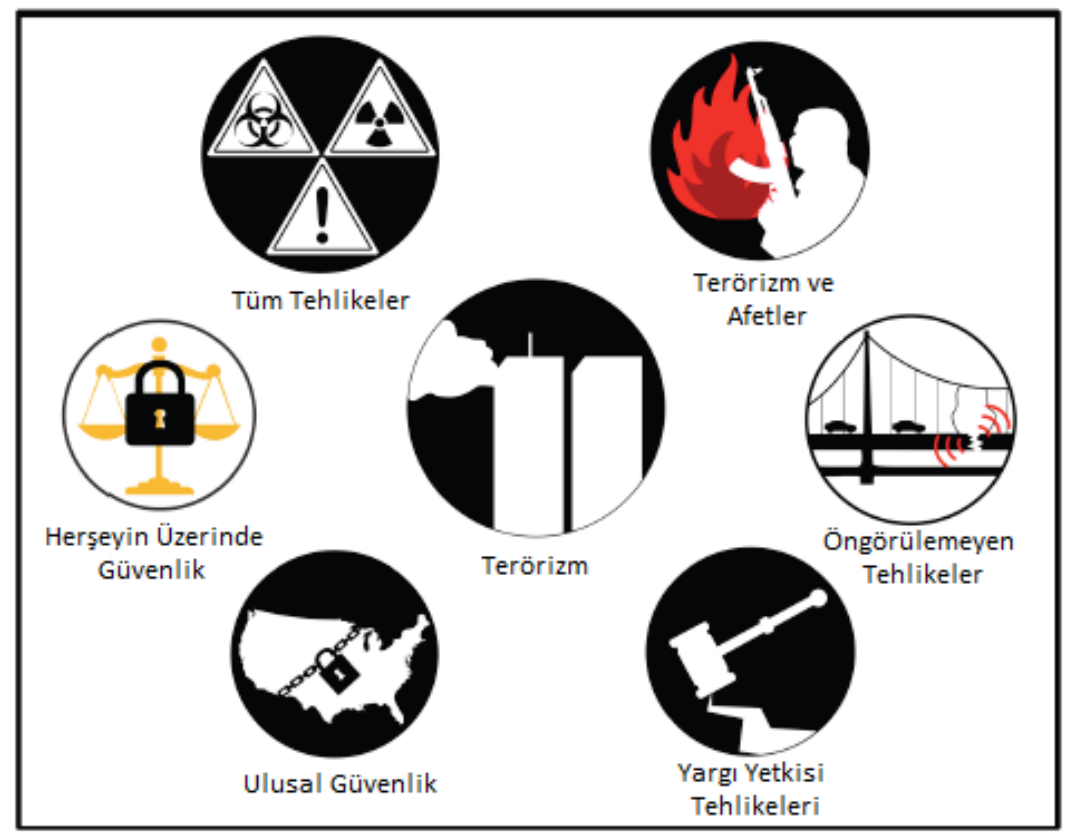

Kaynak:Bellavita, Christopher, (2008), "Changing Homeland Security, s. What isHomeland Security?”, Homeland Security Affairs, 4(2), ss.1-30.

\section{Şekil 1. İç Güvenlik Nedir?: Yedi (7) Tanım}

İç güvenlik kavramına ilişkin olarak Türkiye'de resmi bir tanım bulunmamakla birlikte ilgili hususta literatürde de çok fazla bir birikim bulunmamaktadır. İç güvenliğin kapsamı noktasında yukarıda sayılan unsurların tümü düşünüldüğünde bir makalede çalışılabilecek kadar sınırlı olmadığı gerçeği göz önünde tutularak bu makalede iç güvenlik kavramına ilişkin olarak kamu güvenliği hususunun sağlanması noktasında Türkiye'de yeni ve ideal bir iç güvenlik yapılanmasının nasıl olması gerektiği sonucu ortaya konulmaya çalışılacaktır.

\section{Türkiye'nin Mevcut i̇ç Güvenlik Yapısı}

Ülkelerin sosyal, ekonomik ve siyasi olarak her bakımdan gelişebilmesi, geleceğe dair endişeler taşımaması o ülkede iç huzurun sağlanmış olması ile ilgili olduğu belirtilmekte ve durumun ancak mevcut hukuk sisteminin çağa uygun şekilde tesis edilerek işletilmesi ile sağlanabileceği ifade edilmektedir. İlgili hukuk sisteminin işletilmesi ve böylece başıboş, 
düzensiz ve güvensiz bir ortamın oluşmasının önüne geçilmesi güvenlik güçlerinin varlığına bağlanmaktadır (Karatepe, 2016, s. 28).

İç güvenlik yönetiminde tekli sistemin uygulandığı ABD, Almanya ve İngiltere gibi ülkelerde kentsel ve kırsal bölge ayrımı olmaksızın tüm alanlardan polis sorumlu iken iç güvenliğin sağlanabilmesi için birden çok teşkilatın kurulu olduğu çoklu sistem olarak adlandırılan ve ülkemizde de uygulanan sistemde ise şehir merkezlerinin güvenliği polis tarafından; köy, kasaba gibi kırsal alanların ve polisin bulunmadığı bölgelerin güvenliği ise jandarma tarafindan sağlandı̆̆ı görülmektedir (Köksal, 2014, s. 24).

Ülkemizde iç güvenlik, kolluk kuvvetleri tarafindan sağlanmakta olup ilgili iç güvenlik/kolluk hizmetleri yani kamu düzeninin korunması ve kamu güvenliğinin sağlanması görevi ana örgütlenme şeklinde İçişleri Bakanlığ (Yılmaz, 2001a, s. 39). Bu görevi genel kolluk anlamında İçişleri Bakanlığı'na bağlı olarak Emniyet Genel Müdürlügü, Jandarma Genel Komutanlığı, Sahil Güvenlik Komutanlığı yerine getirirken, özel kolluk olarak ise kısmen de olsa Gümrük Muhafaza Memurlukları, Orman Muhafaza ve Belediye Zabitaları tarafından yerine getirilmektedir. Genel kolluk ve özel kolluğun olmadığı durumlarda yardımcı kolluk olarak görev yapan Köy Korucuları, Köy Bekçileri, Kır Bekçileri, Kıyı Emniyeti, Liman Kolluğu ve Çiftçi Mallarını Korumapersonelleri kolluk kuvvetlerine yardımcı olarak ilgili görevi ifa etmektedirler.

DPT tarafından IX. Kalkınma Planı çerçevesinde hazırlanan “Adalet Hizmetleri ve Güvenlik" adlı özel ihtisas komisyonu raporunun, “Ülkemizde Durum” başlıklı bölümünde; ...Bu çerçevede değerlendirildiğinde ülkemizde İçişleri Bakanlığına bağlı Emniyet Genel Müdürlüğü, Jandarma Genel Komutanlığı ve Sahil Güvenlik Komutanlığı’nın genel kolluk gücünü oluşturdukları, bu kuruluşların yanı sıra Milli İstihbarat Teşkilatı (MİT) Müsteşarlığı, Gümrükler Muhafaza Genel Müdürlüğü, Kaçakçılık İstihbarat Harekat Bilgi Toplama Daire Başkanlığı (KİHBİ), Mali Suçları Araştırma Kurulu (MASAK) Başkanlığı ve Afet ve Acil Durum Yönetimi Başkanlığı’nın (Eski, Sivil Savunma Genel Müdürlüğü) da güvenlikle ilgili diğer kamu kurum ve kuruluşları olduğu... şeklinde bir ifade bulunmaktadır (DPT, 2007, s. 3).

Bu ifadeye ilişkin olarak Yılmaz (2011a), ciddi bir çalışma yapılması durumunda, Türkiye'de iç güvenlikle ilgili örgütlerin hangilerinin olduğu konusunda net bir tanımlamanın rahatlıkla yapılabileceğini dile getirmektedir (Yılmaz, 2001a, s. 46). Buradan hareketle bu çalışmada Türkiye'de iç güvenlikle ilgili örgütlerin hangilerinin olduğu hususu üzerine, "Türkiye'de Mevcut İç Güvenlik Yönetim Yapısı" (Tablo 1) başlığı altında, yapılan son düzenlemelerle birlikte geniş bir şekilde ortaya konulmaya çalışılmıştır. Ancak çalışmanın kısıtları dikkate alındığında böyle bir çalışmada tüm iç güvenlik unsurlarına değinilmesinin olanaksız olduğu görülmekte olup bu anlamda çalışmanın asıl konusunu oluşturan ve İçişleri Bakanlığı’na bağlı olarak hizmet veren “Genel Kolluk Kuvvetleri” hususu irdelenmektedir. 
Tablo 1. Türkiye'nin Mevcut İç Güvenlik Yapısı

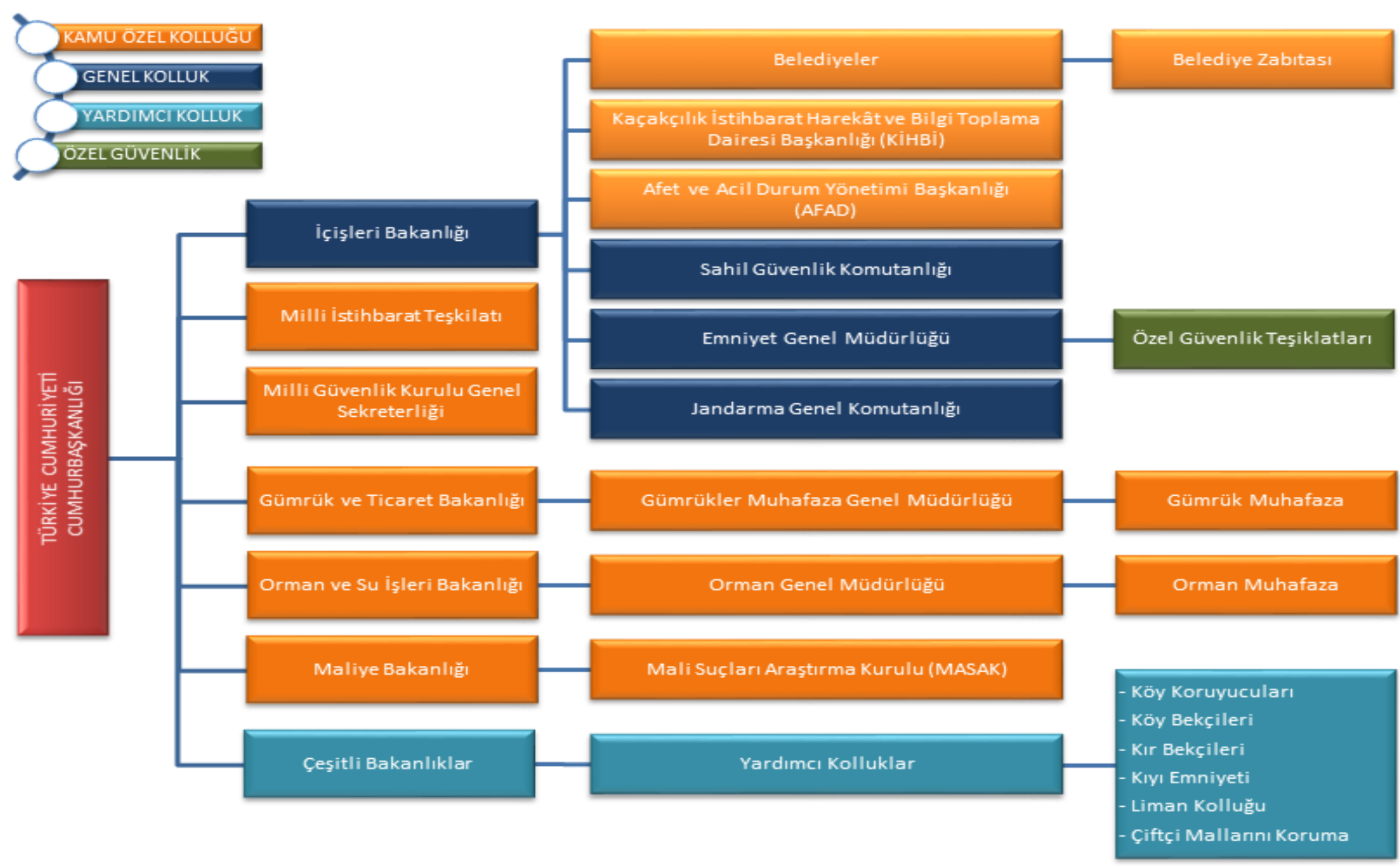




\section{Türkiye'nin İç Güvenlik Sisteminde Yaşanan Sorunlar ve Çözüm Önerileri: Karşılaştırmalı Bir Yaklaşım}

İç güvenliğin sağlanması ulus devletlerin temel hedefleri arasındadır. Devletlerin tarihsel süreçte edinmiş oldukları güvenlik kültürleri, yönetim şekilleri, halklarının güvenlik konusundaki talep ve ihtiyaçları ve iç güvenliği tehdit eden etmenler farklılık gösterdiğinden devletlerin iç güvenlik yapıları da farklılık göstermektedir. Türkiye Cumhuriyeti'nin iç güvenlik yapısı da ordu-millet tabanlı güvenlik kültürünün etrafında şekillenmiş, Tanzimat döneminde Fransız etkisi altında polis ve jandarmadan oluşan ikibaşlı güvenlik yapısı oluşturulmuştur. Günümüzde de iç güvenliğin sağlanması polis ve jandarma teşkilatlarının görev ve sorumluluğunda bulunmaktadır. Türk sisteminde de görüldüğü üzere devletlerin birbirlerinin iç güvenlik sistemlerini ihraç etmeleri ya da zamanla iç güvenlik sisteminde reform niteliğinde yenilikler yapmaları olağan bir durumdur. Nitekim güvenlik, risk ve tehditlerin değişmesiyle doğru orantılı bir biçimde stratejik yenilenme ve etkileşim gerektiren bir alandır. Artan suç ve terör olayları, terörün ulus devletin sınırlarını aşması, organize yapılanmalar gibi etmenler ulus devletlerin, diğer devletlerin iç güvenlik sistemlerinin nasıl düzenlendiğini ve mevcut yapının suçla mücadelede etkin olup olmadığını irdelemeleri gerektirmektedir. Son yıllarda az sayıda da olsa diğer devletlerin iç güvenlik yapılarını inceleyen ya da Türkiye’nin iç güvenlik sistemini diğer başka devletlerin iç güvenlik sistemleri ile kıyaslayan karşılaştırmalı akademik çalışmalar yapılmış ve bazılarında Türkiye'nin iç güvenlik sisteminin nasıl şekillendirileceği ile ilgili görüşlere yer verilmiştir. Fakat 15 Temmuz 2016'dan -Türkiye Cumhuriyeti'ne yapılan darbe girişiminden-önce yapılmış olan akademik çalışmalar Türkiye Cumhuriyeti'nin darbe girişiminden sonra iç güvenlik sistemini nasıl revize etmesi gerektiği hususundaki araştırma sorusunu cevaplayabilecek nitelikte değildir. Tehdit olgusunun değiştiği, devlet yapılanmasına paralel bir yapılanmanın devletin iç güvenlik mekanizmasına gizlendiği, güvenliği sağlamakla yükümlü olan sistemin devletin güvenliğini tehdit ettiği bir koşul altında devletin iç güvenlik sisteminin yeniden şekillendirilmesinin ve iç güvenlik sisteminde stratejik yenilenmeye gidilmesinin zorunluluğu açık bir şekilde görülmektedir. Türkiye Cumhuriyeti'nin iç güvenlik sistemindeki ilgili durumlar göz önüne alınarak yapılan bu çalışmada, diğer devletlerin iç güvenlik sistemleri incelenerek Türkiye Cumhuriyeti'nin iç güvenlik sisteminin nasıl revize edilmesi gerektiği sorusunun yanıtlanması amaçlamaktadır. Bu noktada Türkiye'nin iç güvenlik sisteminde karşılaşılan sorunların temel sebepleri aşağıda sıralanmaktadır:

1. İç güvenlik teşkilatları arasındaki koordinasyon ve istihbarat paylaşımı problemi,

2. Polis ve jandarma personelinin işe alımlarında dikkate alınacak, terfilerinde motivasyon sağlayacak unsurlara ve ilgili personele karar alıcı ve problem çözücü niteliklerin kazandırılmasına ilişkin problemler,

3. Çalıştığı bölgeye, bölgenin şartlarına, sosyo-kültürel yapısına hakim olmayan iç güvenlik personelinin görev yerinde etkin olamaması, 
4. İç güvenliğin bir halk hizmeti olarak algilanmaması,

5. Emniyet teşkilatının FETÖ ve benzeri oluşumlardan arındırılması,

6. İç güvenlik sisteminin yeni bir model ile yapılanması gereği.

Yukarıda sıralanan Türkiye'nin iç güvenlik yapısına ilişkin sorunların temel sebeplerine dair çözüm önerileri ise aşağıda başlıklar halinde irdelenmektedir.

\section{iç Güvenlik Teşkilatları Arasındaki Koordinasyon ve istihbarat Paylaşımı Problemlerine iliş̧in Çözüm Önerileri}

Türkiye'de olduğu gibi iç güvenliğin jandarma ve polis teşkilatları tarafından sağlandığı Arjantin'de de federal polisin, eyalet polisinin ve jandarmanın görev sahasının tam olarak belirlenmemesi iç güvenlikte ve iç istihbaratta sıkıntılara neden olmaktadır (Özer, 2006, s. 111). Türkiye'nin iç güvenlik yapısına benzer bir teşkilatlanmaya sahip bir başka ülke olan Belçika'ya bakıldığında, 1980'li yıllarda iç güvenlikle ilgili sorunlar yaşayan Belçika'nın 1991 yılında anayasada yapılan değişikliklerle jandarmanın askeri görünümünü kaldırdığı ve sivilleştirdiği görülmektedir (Çevik, vd., 2005, s. 108). Toplumsal olaylarda hazır kuvvet polisi görev yapmaktadır. Bu tip olaylarda idari makamların polis olanaklarını yeterli görmediği durumda askeri unsurlardan yardım isteme yetkileri bulunmamaktadır. Askeri birliklere silahlı ayaklanmalar dışında toplumsal olaylara müdahale hakkı verilmemektedir (Akar, vd., 2005, s. 84).

Bununla birlikteKalkınma Bakanlığı Onuncu Kalkınma Planı (2014-2018) "Güvenlik" başlğında güvenlik hizmetlerinin mevcut durumuna ilişkin durum analizi yapilırken, "Güvenlik hizmetlerinin gerek kurumsal gerekse işlevsel niteliğinin artırılması, güvenlik birimlerinin yetki ve görev çakışmalarının önlenmesi, önleyici ve koruyucu hizmet sunumunda etkinliğin artırılması, kurumlar arası koordinasyonda etkinliğin sağlanması ile güvenlik birim ve faaliyetleri üzerinde sivil denetimin daha da güçlendirilmesi" gibi hususların önem arz ettiği ifade edilmektedir. Yine aynı plan içerisinde güvenlik hizmetlerinin sağlanmasında, güvenlik birimlerine ilişkin mevzuatın iyileştirilmesi, organizasyon sorunlarının giderilmesi, hizmet sunumunda kurumlar arasinda daha etkin bir koordinasyonun sağlanması gerektiği birer politika olarak yer almaktadır (Onuncu Kalkınma Planı, 2013, s. 36-37). Buradan hareketle, iç güvenliği sağlayan hizmet birimleri arasında bir koordinasyon problemi olduğu tespit edilmekte ve ilgili sorununkalkınma planında bir politika olarak yer aldığı anlaşılmaktadır. Bu nedenle polis ve jandarma teşkilatları arasındaki koordinasyon ve istihbarat paylaşımı problemi, iç güvenlik sisteminin yeniden revize edilmesini gerektiren nedenlerden biri olarak ifade edilmektedir. Son düzenlemelerden önce Jandarmanın, eğitim-öğrenim yönüyle Genel Kurmay Başkanlığı, kolluk hizmetleri yönüyle İçişleri Bakanlığı, denetim yönüyle Milli Savunma Bakanlı̆̆ (Karaman, 2006, s. 16) gibi farklı devlet kurumlarına bağlı olmasının,Jandarma teşkilatının eğitim, kolluk hizmetlerinin sağlanması ve denetimi gibi görevleri yönünden aynı 
zamanda polis ve jandarma arasındaki görev, yetki ve istihbarat paylaşımı noktalarında bir takım problemlerin ortaya çıkmasına zemin hazırladığı görülmektedir. $\mathrm{Bu}$ durumun sonucu olarak ortaya çıkan jandarma teşkilatının yaşadığı kimlik karmaşasının önlenmesi iç güvenliğin sağlanmasının temel koşullarından biri olarak karşımıza çıkmaktadır.

$\mathrm{Bu}$ anlamda 668 sayılı olağanüstü hal kararnamesi ile Jandarma Genel Komutanlığı'nın ve Sahil Güvenlik Komutanlığı'nın İçişleri Bakanlığı'na bağlanması iç güvenlik sistemindeki koordinasyonsuzluk ve kimlik karmaşasının önüne geçmeyi hedefleyen bir adım olarak görülmektedir. Bir sonraki adım jandarma ve polis teşkilatlanmalarının eğitim ve istihbarat paylaşımı hususlarında da ortak bir çerçeve altında toplanmalarının sağlanması ve jandarma teşkilatının sivilleştirilmesinin hızlandırılması olmalıdır.

Diğer bir problem olarak ise Devlet Planlama Teşkilatı (DPT) tarafından 9. Kalkınma Planı Çerçevesinde hazırlanan "Adalet Hizmetleri ve Güvenlik" isimli ihtisas raporunun "Durum Analizi" bölümünde Türkiye'de adli kolluk ile genel kolluk arasında görev ve yetki alanı sınırlarını belirleyen bir yasal düzenleme bulunmadı̆̆ı belirtilerek, "Polis ve jandarma gibi genel idarî kolluk amacıyla verilen önleyici güvenlik ve asayiş hizmeti veren kamu hizmet birimleri dışında, tamamen yargıya bağlı ve çağdaş adlî güvenlik hizmeti standartlarında adalet hizmeti veren bir adlî kolluk örgütünün henüz kurulamamış olması" sistemin güçsüz bir yönü olarak gösterilmiştir (DPT, 2007, s. 41). Bu noktada yönetsel kolluk ve adli kolluk arasında yapılan ayrımın, iç güvenliği sağlayan birimlerin görev ve işleyişleri açısından problemli bir konu olduğu görülmekte olup yönetsel kolluk ve adli kolluk ayrımına ilişkin muğlaklığı ortadan kaldıracak yeni düzenlemelerin ortaya konulması gerekmektedir.

Polis ve Jandarma Personelininişe Alımlarında Dikkate Alınacak, Terfilerinde Motivasyon Sağlayacak Unsurlara ve ilgili Personele Karar Alıcı ve Problem Çözücü Niteliklerin Kazandırımasına ilişkin Çözüm Önerileri

Polis ve jandarma personelinin işe alımlarında dikkate alınacak, terfilerinde motivasyon sağlayacak unsurlara ve ilgili personele karar alıcı ve problem çözücü niteliklerin kazandırılmasına ilişkin birkaç öneri sıralamak mümkündür. Bu anlamda;

- Aday polislik uygulamasının hayata geçirilmesi ve kişinin mesleğe bağlılığının örgütsel boyuta taşınması,

- Adaylık süresincekişinin geçmişine yönelik sıkı bir incelemenin yapılması ve meslek hayatı içerisinde davranışlarının incelenmesi,

- Polisin ve Jandarmanın çalışma saatlerinin düzenlenmesi, bu anlamda çalışma saatlerine ilişkin stresin ortadan kaldırılması,

- Mesleğe ve sosyal yaşama dayalı psikolojik testlerin uygulanması, 
- Polis ve Jandarma personelinde olaylar karşısında karar alma bilincini güçlü kılacak hukuksal korumanın hayata geçirilmesi,

- Hukukçuların polislik görevinde bulunmasının önünün açılması yahut kolluk kuvveti bilincinin yanı sıra karşılaşılabilecek olayların çeşitliliği nedeniyle sıkı bir hukuk bilgisinin edinilmesinin sağlanması,

- Siber suçlarla mücadele için yazılım bilgisine sahip gençlerin polis ve jandarma teşkilatına kazandırılması adına teşvik edici adımların atılması, vb.

Yukarıda irdelenen hususların hayat bulduğu süreçlerin polis ve jandarma personelinin işe alımlarında ve terfilerinde uygulanması durumunda şeffaflık ve liyakat ilkelerinin yerine getirilmesinin mümkün olabileceği düşünülmektedir.

\section{Çalıştığı Bölgeye, Bölgenin Şartlarına, Sosyo-Kültürel Yapısına Hakim Olmayan iç Güvenlik Personelinin Görev Yerinde Etkin Olamaması ilişkin Çözüm Önerileri}

İngiliz ve Amerikan polis eğitim sisteminin pratiğe yönelik olduğu ancak Türk Polis eğitim sisteminde teoriye ağırlık verildiği ve bu anlamda eğitimlerde gerçek durumların oluşturulamadığı belirtilmektedir (Doğutaş, vd., 2007, s. 14). Diğer bir örnekte Güney Afrika Polis Servisi'nde toplum destekli polislik hizmetinin "Sektör Polisliği" adı altında uygulanmakta olduğu görülmektedir. Sektör polisliği, polis merkezlerinin daha küçük ve daha kolay idare edilebilir bölgelerin "Sektör" adı verilen bölümlere ayrılması durumudur. Her bir sektör mıntıkasına sektör amiri olarak görevli bir polis atanmaktadır. Bunlar polis merkezi ve vatandaş arasında irtibat görevlisi gibi çalışmaktadır. Temel amaç suçla mücadele ederken halka ortaklık yaparak onlardan gelecek istihbarata dayalı suç önleme çalışmaları yapmaktır (SAPS, 2015, s. 130-148). Bu açılklamalardan da anlaşılacağı üzere çalıştığı bölgeye, bölgenin şartlarına, sosyo-kültürel yapısına hakim olmayan ya da yabancı olan iç güvenlik personelinin görev yerinde etkin olamaması diğer bir problemi oluşturmaktadır. Bu noktadaki çözüm önerileri;

- Polis memurlarının en az bir yerel dil bilmesi,

- Kürtçe ve Arapça bilen ve bölge şartlarını ve kültürüne hakim vatandaşların polisliğe özendirilmesi ve öncelik verilmesi,

- Bölge kültürü ve yaşam tarzı hassasiyetlerine ilişkin hizmet içi eğitimler ile kurs ve seminerlerin verilmesi,

- Şehirlerin sosyolojik yapısına hakim polislerin yetiştirilmesi,

- Kadın polis sayısının arttırılması ve kadın ve çocuk istismarının daha yoğun yaşandığı bölgelere kadın amir atanmasına öncelik verilmesi vb.

Yukarıda sayılan ilgili çözüm önerilerinin uygulanmasının, iç güvenlik personelinin çalıştığı bölgeye, bölgenin şartlarına, sosyo-kültürel yapısına hakim olmasının ya da yabancılık yaşamayacağı bir ortamda hizmet vermesinin ve görev yerinde etkin olmasının sağlanabileceği düşünülmektedir. 


\section{İ̧ Güvenliğin Bir Halk Hizmeti Olarak Algılanmaması ilişkin Çözüm Önerileri}

Japonya' da polisliğin bir halk hizmeti olarak algılandığı aktarılmaktadır. Japonya'da Koban Sistemi adı verilen modern toplum destekli polis sistemi uygulanmaktadır (Bayley, 1992, s. 7-8). Koban Sistemi; Japonya'da genellikle kent merkezlerinde oluşturulan küçük kulübelerde (koban) suçla mücadele ve çevredeki halka yardım (yalnız yaşayan yaşlıları ziyaret gibi) için polisin 24 saat görev yapması şeklinde tanımlanmaktadır (Sözen, 2003, s. 8). Senede 2 defa bölgelerindeki tüm evleri mutlaka ziyaret eden bu kobanlarda görevli polisler problem odaklı yaklaşımla bölge halkının sorunlarına çözüm arayışında bulunarak suç önlemede başarı sağlamaktadırlar. (Bayley, 1992, s. 7-8). Diğer bir örnekte ise Finlandiya'da her iki yılda bir yapılan Polis Güvenlik Barometre Anketi yoluyla halkın polisi algılamasını ve düşüncesi izlenmekte olduğu ifade edilmektedir. İlk anket 1999 yllında gerçekleştirilmiş ve Polis'e olan güvenin Finlandiya' da çok yüksek olduğu sonucuna varılmıştır (Şimşek ve Köseli 2007, s. 145).

Türkiye'de ise iç güvenliğin sağlanması ve terör sorununun çözümünde alınacak sosyo-ekonomik ve kültürel önlemlerin yanı sıra, bölge halkı ile devlet arasında güvenilirlik sorununun giderilmesi, bölgesel güvenliğin mutlaka sağlanması, saygın, deneyimli ve seçkin kamu personelinin yer alacağı etkin ve dürüst bir kamu yönetiminin kurulması ile birlikte halkın polise olan güveninin artırılması önerilmektedir (Türkiye Barolar Birliği, 2006, s. 600).Bu anlamda Türkiye'nin coğrafi konumunun getirdiği siyasal pozisyonu ve kültürel durumu da düşünülerek aşağıda sıralanan öneriler noktasında atımlar atılmasının uygun olabileceği düşünülmektedir;

- Ortaöğretimde polis teşkilatının tanıtılması,

- Sunumlar ile Polis Akademisinin tanitılması,

- Polis hizmetine ilişkin anketler yapılarak halkın görüşünün alınması ve polisin halkın polisi olarak görülmesinin sağlanması,

- Kolektivist, toplum destekli polislik anlayışının geliştirilerek halkla işbirliğinin sağlanması,

- Polisin yerinde ve orantılı güç kullanımının sağlanması,

- Stratejik düşünme, ikna ve yönlendirme kabiliyeti yüksek polislerin (uzlaşmacı polislik) alanda olmasının sağlanması,

- İş bulamayınca polis olma yerine, polisliğin saygın bir meslek olarak algılanmasının sağlanması vb.

\section{Emniyet Teşkilatının FETÖ ve Benzeri Oluşumlardan Arındırılması}

15 Temmuz 2016 Cuma gecesi Türkiye Türk Silahlı Kuvvetlerinin (TSK) içine uzun süre boyunca sızan Fetullahçı Terör Örgütü’nün (FETÖ) darbe girişimine tanık oldu. Ordu, Emniyet ve pek çok kurumun içerisinde kadrolaşmış bu terör örgütününmensupları ülkenin kritik kurumlarını ele geçirmeye çalışarak kanlı bir 
darbegirişiminde bulundu. Darbe girişimi halkın demokratik tepkisi ve direnişi ile Cumhurbaşkanı Recep Tayyip Erdoğan'ın liderliği sayesinde püskürtüldü (Gülener ve Öztürk, 2018, s.7). Bu anlamda 15 Temmuz sonrasında terör eylemlerini tırmanışa geçirmeye çalışan FETÖ, PKK ve DEAŞ gibi terör örgütlerinin Türkiye'de kaos ortamı oluşturmaya çalıştıkları ve bu kaos ortamıyla Türkiye'de vatandaşlar nezdinde güven bunalımı oluşturmayı ve uluslararası toplumda ülkenin güvenlik ve istikrar açısından imajını zedelemeyi amaçladıkları ifade edilmektedir (Ulutaş, 2016, s. 1).

Güvenlik hizmetlerinin tam kamusal mal ve hizmet niteliği taşımakta ve devletin üstlendiği asli görevler arasında olduğu göz önüne alınırsa, terör faaliyetleri ile mücadelede güvenlik hizmetinin önemli bir rol oynadığ 1 görülmektedir. $\mathrm{Bu}$ noktada FETÖ’nün emniyet ve askeri alanda diğer suç ve terör örgütlerinden farklı bir yönteme sahip olduğu, öyle ki emniyet ve askeri alanda diğer suç ve terör örgütleri yöntem olarak adam satın alma, tehdit ve benzeri yöntemler izlerken FETÖ terör örgütünün adliye, mülkiye, askeriye ve emniyet başta olmak üzere tüm devlet organlarında Cumhuriyet tarihinde eşi görülmemiş yaygınlık ve derinlikte kadrolaştığı ifade edilmektedir.Sızma faaliyetinde sabırlı davranan FETÖ’nün, Emniyet teşkilatında ele geçirilmesi gereken ilk hedef olarak teşkilatın eğitim kurumlarını seçtiği, Polis Akademisi, kolejlerve meslek okullarına sızan örgütün buralardan mezun olan mensuplarını Emniyetinstratejik kurumlarındaki mevcut elemanlarının yardımıyla kitlesel kadrolaşmada kullandığı, kadrolaşma için stratejik ve operasyonel müdürlüklerin ve şubelerin öncelendiği,Emniyet teşkilatının diğer birimlerine yerleştirilenlerinse yedektetutulduğu, hakimiyet kurmak istedikleri birimlerde kendileriyle birlikte hareket etmeyi reddedenlerinörgüt tarafından tehdit ve şantajla baskı altına alındığı veya tasfiye edildiği ifade edilmektedir (Gülener ve Öztürk, 2018, s.53).

Anayasal düzeni yıkarak kendi egemenliğinde bir devlet idaresi kurma hedefi doğrultusunda planlı bir şekilde hareket ettiği belirtilen örgütün, 2013 yılı sonrasında çeşitli yöntemlerle darbe yapmaya teşebbüs ederek doğrudan iktidarı ele geçirmeye çalıştığı görülmektedir (Uzun, Akgün ve Yücel, 2017, s. 11-14). Ancak karşımızdaki örgütün Cumhuriyet tarihimizin neredeyse yarısı kadar sürede devlet kademelerine sızmayı amaç edinmesinden dolayı, dünyadaki uygulamalardan farklı olarak söz konusu arındırma sürecinin farklı bir bağlam içinde hareket edilmesini zorunlu kıldığı belirtilmektedir(Gülener ve Öztürk, 2018, s.53).Bu anlamda arındırmanın bir devlet politikası olarak toplu/örgütlü biçimde suça bulaşmış kamu görevlilerinin bulundukları makamlardan uzaklaştırılmaları ile gözaltına alma ve tutuklama gibi idari ve yargısal süreçleri de kapsayan bir durum olduğu göz önüne alınırsa, FETÖ’nün devletten arındırılmasının hızlı ve kolay olmayacağının uygulayıcılar ve toplum nezdindeki idrakinin önemli olduğu, ancak bunun kadar önemli başka bir hususun ise mücadele kararlılığının hukuk devleti ve demokrasi kuralları çerçevesinde, özellikle toplum desteğinin kaybedilmeden 
sürdürülebilmesiolduğu ifade edilmektedir (Gülener, 2017, s. 1).Tüm bunlarla birlikte FETÖ’nün, taşıdığı karakter itibarıyla özgün bir yöntemle mücadele edilmesi gereken bir terör örgütü olduğu, bu mücadelenin en önemli ayağını arındırma sürecinin oluşturduğu dile getirilmektedir (Gülener, 2017, s. 1). Çünkü 15 Temmuz darbe girişimi sonrasında ihraç edilen, gözaltına alınan ve tutuklananların profilleri FETÖ’nün devletin kurumlarına ne denli köklü ve yaygın bir biçimde sızdı̆̆ını ortaya koymaktadır (Demir ve Çağlar, 2017, s. 15).

Dini bir motivasyonla yola çıktığını iddia eden ve bu sav etrafında on binlerce insanı gayrimeşru amaçları doğrultusunda mobilize edip (Demir ve Çağlar, 2017, s. 45),devlet kademelerine sızmasına hakim olan iki ana unsura "gizlilik" ve “takiye” olan (Gülener ve Öztürk, 2018, s. 69). ve bu vesile ile devletin kurumlarında önemli noktaları tutan bir yapının PKK gibi terör örgütleri ile de bağlantıları düşünüldügünde gerek istihbarat gerekse güvenlik açığı oluşturması bakımından iç güvenliği tehdit eden çok büyük bir unsur halini almıştır. Diğer yandan Suriye'den sızan yabancı uyruklu DAEŞ unsurlarının ve bunun yanında PKK terör örgütünün sivil hedeflere yönelik gerçekleştirebileceği eylemlerin minimize edilebilmesi, FETÖ ve benzeri oluşumların devlet kademelerinden arındırılması ve tekrar bu gibi kademelerde yer edinememesi adına Türkiye Cumhuriyeti'nde neredeyse elli yıla yakın bir süredir devletesızmayı amaç edinen bir örgütle mücadele edenler tarafından, FETÖ'nün devlete sızmak için izlediği stratejileri çok iyi analiz edilmesi ve başta toplum olmak üzere tüm muhataplara örgütün tüm güvenlik hizmetleri bakımından nasıl bir tehlike arz ettiğinin iyi bir şekilde anlatılması ile mümkün olabilecektir.

\section{İç Güvenlik Sisteminin Yeni Bir Model İle Yapılanması Gereği}

Günümüzde teknolojik gelişmeler, toplumların sosyo-ekonomik ve politik yapılarındaki değişimler, suçların tür, nitelik ve sayısında görülen değişmeler ve halkın güvenlik hizmeti sunanlardan beklentilerinin değişmesi gibi faktörler ülkelerin iç güvenlik örgütlerinde yeniden yapılandırmayı gerektiren nedenler olarak sıralanmaktadır. Bu değişimlere sebep olan iç ve diş çevresel faktörler arasinda en belirgin ve de etkili olanları:

- Terör örgütlerinde gözlemlenen değişimler,

- İstihbarat alanında yaşanan değişimler,

- Hizlı teknolojik değişimler,

- Silah sistemlerindeki değişimler (Yılmaz, 2011a, s. 52),

- Asimetrik tehditler (Kimyasal, Biyolojik, Radyolojik, Nükleer),

- Havalimanlarındaki çok başlı güvenlik yönetiminin doğurduğu güvenlik açı̆̆ 1 ,

- Terör örgütlerinin insansız hava araçlarını ve lazer silahları kullanmasışeklinde özetlenmektedir. 
Tüm bunlarla birlikte güvenlik bağlamında, "dolaşım" medeniyetin, insan, enerji, finans, sermaye, gıda, su gibi zenginliklerinin yanı sıra uyuşturucu, kara para, pandemik hastalıklar gibi zenginlik sayılmayacak unsurlarının etkileşimi ve hareketi olarak tanımlanmaktadır. Toplumsal unsurların bu karmaşık hareketi ülkelerin iç güvenliğini ve dış savunmalarını operasyonel ve yönetim anlamında birbirine bağlamasının yanı sıra bu gibi sorunlarla başa çıkma ihtiyacını da beraberinde getirmektedir(Caudle, 2009, s. 2-3).

Yukarıda da ifade edildiği üzere güvenlik bağlamında, "dolaşım" kavramının gereğitoplumsal unsurların hareketinin yoğun bir şekilde gerçekleştiği önemli yerlerden birisi de havalimanlarıdır. Bu anlamda 28 Haziran 2016 tarihinde Atatürk Havalimanı'nda 46 kişinin hayatını kaybettiği, 234 kişinin yaralandığı DEAŞ terör örgütü tarafından gerçekleştirilen terör saldırısı da havalimanlarının terör örgütleri tarafından düşman hedef olarak görülmesi ve buralarda gerçekleştirilen terör eylemlerinin ses getirmesi ülkemizdeki havalimanlarında çok başlı güvenlik yönetimi anlayışının da sürdürülemez olduğunu ortaya koymaktadır.Buradan hareketle iç güvenlik sisteminin yeni bir model ile yapılanması başlığı altında,iç güvenliğin önemli bir unsuru olması bakımından havacılık ve havalimanları güvenliğinin tek elden yönetimi hususu da zorunluluk olarak karşımıza çımaktadır (Demirkol ve Nalla, 2017, s. 171-172).

Tüm bunların dışındaterör örgütlerinin sistemde sürekli açık arayan tarafları da göz önüne alındığında yukarıda sıralananlara ek olarak güvenlik kavramı üzerindeki değişikliklerin etkenleri geniş bir şekilde ele alınmıştır. Bunlar:

- Nüfus bakımından zengin Çin ve Hindistan'ın yükselişi, enerji açısından zengin devletlerin ve bölgelerin artan önemi ve ulus devletler içerisindeki güç dağılımlarının değişimi,

- Terör örgütleri ve organize, uluslararası suç örgütleri gibi devlet dışı aktörlerin gücündeki artış,

- Kitle imha silahlarının yaygınlaşması,

- Doğal felaketlerin yıkımı,

- Toprağa, suya, ormanlara ve balıkçllğga zarar veren çevresel ve ekolojik faktörlerin sebep olduğu stres,

- Ekonomik büyüme planlarında değişikliğe ve gıda ve su kıtlığına sebep olan iklim değiş̧ikliği,

- Küresel yoksulluk, zengin ve fakir arasındaki gelir dağılımındaki adaletsizlik ve küresel ekonomik sistemdeki istikrarsızlık,

- İnsan haklarına saygıda ve bunların korunmasındaki zayıflıklar, etkisiz olduğu düşünülen uluslararası hukuk düzeni gibi faktörler olarak sıralanmaktadır. 
Bu faktörlerin her birinin tek tek veya toplu olarak güvenlik tehditlerine dönüştüğü ve güvenlik politikalarını oluşturanların, etkin ve verimli bir iç güvenlik yapısı oluşturabilmeleri için ilgili tüm faktörleri kategorilere ayırmaları gerektiği ifade edilmektedir (Caudle, 2009, s. 2-3). Ancak tüm ulusal ve uluslararası boyuttaki tehditlerin oluşturabileceği güvenlik açığının yanı sıra 15 Temmuz darbe girişiminin toplumsal ve siyasal olarak ülkemizde yarattığı travmanın anlaşılabilmesi ve aşılabilmesi için Fetullahçı Terör Örgütü’nün (FETÖ) devlete nasıl sızdığının ve bunun darbe girişimine giden süreçteki etkisinin analiz edilmesinin bir zorunluluk olarak karşımıza çıktığı diğer yandan ortaya çıktığı tarihten itibaren belirli hedeflere ulaşmak için hareket etmiş ve bunun için karşılaştığı her türlü engelde ve yeni durumda hareket tarzını değiştirmiş olan FETÖ'nün, sadece devlete sızmayı değil tüm bileşenleri ile devlet aygıtını ele geçirmeyi ve Türkiye dahil birçok ülkede bütün kamusal alanı ele geçirerek ülkelere yön vermeyi amaç edinen bir terör örgütü (Gülener ve Öztürk, 2018, s. 9) olduğu da düşünülürse, tüm bu ve benzeri örgütlerin ülkemizin Askeriye, Mülkiye, Adliye, Emniyet ve diğer kamu kurum ve kuruluşlarında yeniden yer edinememesi ve bu mücadelenin sürdürülebilir olabilmesi adına Türkiye'de iç güvenlik sisteminin yeni bir model ile yapılanması gereğinin elzem bir durum olarak ortaya çıktığı görülmektedir. 


\section{Tablo 2.Yeni Bir İç Güvenlik Yapılanma Modeli}

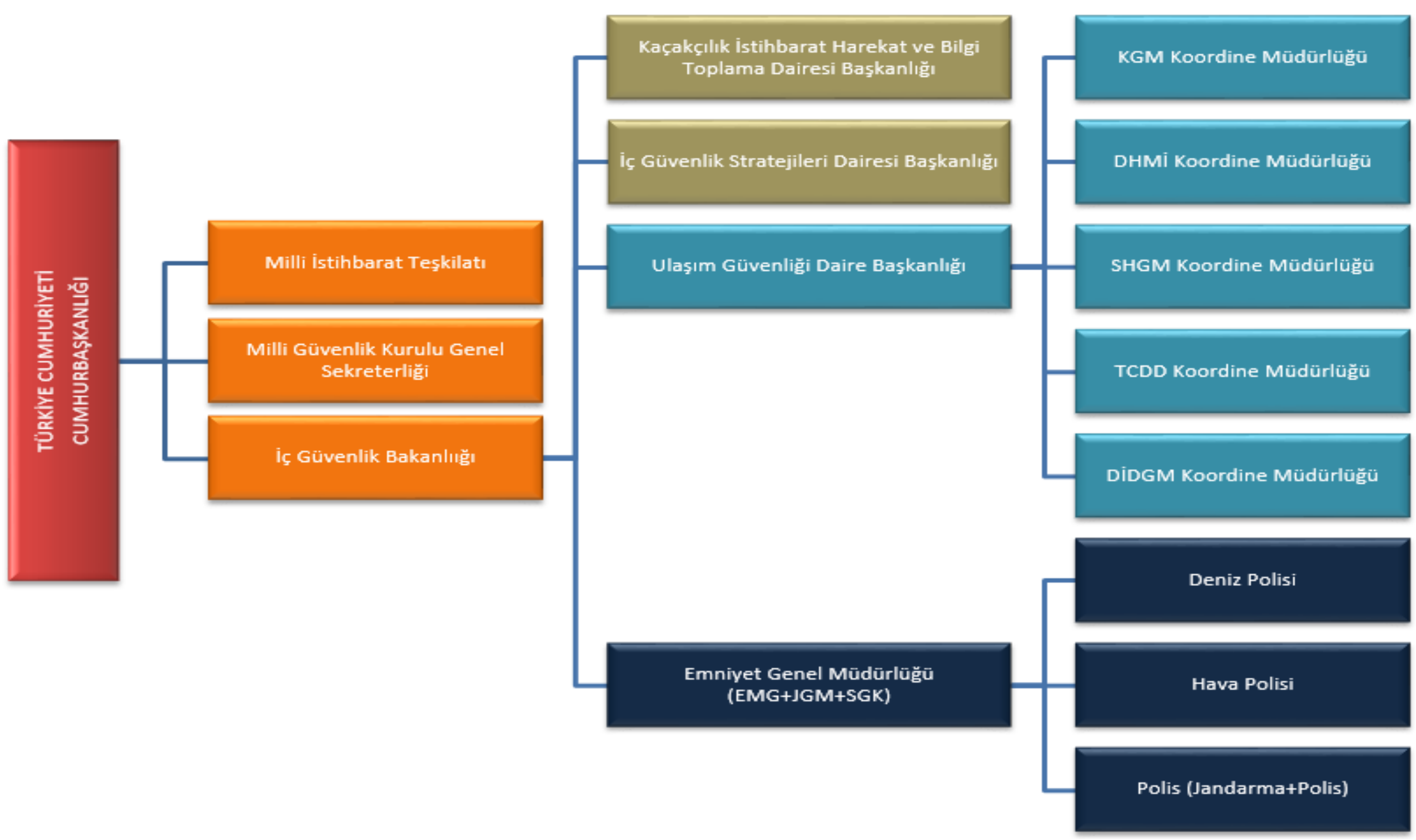




\section{Sonuç}

Adalet, savunma, diplomasi, eğitim, sağlık ve sosyal güvenlik gibi halkın gündelik faaliyetlerini huzur ve güvenlik ortamı içinde sürdürmelerine olanak veren kamusal hizmetlerin yerine getirilmesi noktasındamükellef olan devletin ilgili kamusal hizmetleri ülkede terörün ortaya çıkmasının önünde bir engel oluşturmaktadır. Bu anlamda iç güvenliğin sağlanması da ulus devletlerin temel hedefleri arasındadır. Devletlerin tarihsel süreçte edinmiş oldukları güvenlik kültürleri, yönetim şekilleri, halklarının güvenlik konusundaki talep ve ihtiyaçları ve iç güvenliği tehdit eden etmenler farklılık gösterdiğinden devletlerin iç güvenlik yapıları da farklılık göstermektedir. Türkiye Cumhuriyeti’nin iç güvenlik yapısı da ordu-millet tabanlı güvenlik kültürünün etrafında şekillenmiş, Tanzimat döneminde Fransız etkisi altında polis ve jandarmadan oluşan iki başlı güvenlik yapısı oluşturulmuştur.

Türkiye'nin iç güvenlik sorumluluğu 3201 sayılı Emniyet Teşkilatı Kanunu'nun 1. maddesine göre İçişleri Bakanlığı’na verilmiştir. Bakanlık bu görevi Jandarma Genel Komutanlığı, Emniyet Genel Müdürlügü ve Sahil Güvenlik Komutanlığı vasıtasıyla yerine getirmektedir. Ayrıca; gümrük kapılarında meydana gelen iç güvenlik olaylarına müdahale etme yetkisi Gümrük Muhafaza Genel Müdürlüğüne verilmiştir. Bunların yanında Kara Kuvvetleri Komutanlığına bağlı sınır birlikleri de sınırların güvenliği ve meydana gelen kaçakçılık, sınır ihlalleri vb. görevleri yönünden kolluk yetkilerine sahiptirler. Bu açıklamalardan da anlaşacağı üzere iç güvenlik hizmetlerinin çok başlı bir yapıya, karmaşık bir mevzuata, birbirinden farklı bir hiyerarşiye, sorumluluk alanına, personel yapısına ve eğitim standartlarına sahip olduğu görülmektedir (Mil, 2014, s. 55-56).

Ülkemizde kamu düzenini sağlamak ve adli kolluk görevini yerine getirmek jandarma ve polisin görevi olmakla birlikte mevzuat ve uygulamalarda bazı çelişkiler ortaya çıkmaktadır. Yasal düzenlemelere bakmak ve yeniden yapılandırmanın nasıl ve nerelerde olabileceğini iyi saptamak gerekmektedir (Zengin, 2014, s. 29). Bu anlamda 668 sayılı olağanüstü hal kararnamesi ile Jandarma Genel Komutanlığı'nın ve Sahil Güvenlik Komutanlığı’nın İçişleri Bakanlı̆̆ı'na bağlanması iç güvenlik sistemindeki koordinasyonun sağlanmasını ve kimlik karmaşasının önüne geçmeyi hedefleyen bir adım olarak görülmektedir. Bir sonraki adım jandarma ve polis teşkilatlanmalarının eğitim ve istihbarat paylaşımı hususlarında da ortak bir çerçeve altında toplanmalarının sağlanması ve jandarma teşkilatının sivilleştirilmesinin hızlandırılması olmalıdır.

Diğer yandan ülkemiz iç güvenlik sistemindeki;

a) İç güvenlik teşkilatları arasındaki koordinasyon ve istihbarat paylaşımı problemi,

b) Polis ve jandarma personelinin işe alımlarında dikkate alınacak, terfilerinde motivasyon sağlayacak unsurlara ve ilgili personele karar alıcı ve problem çözücü niteliklerin kazandırılmasına ilişkin problemler,

c) Çalıştığı bölgeye, bölgenin şartlarına, sosyo-kültürel yapısına hakim olmayan iç güvenlik personelinin görev yerinde etkin olamaması,

d) İç güvenliğin bir halk hizmeti olarak algılanmaması, 
e) Güvenlik hizmeti sunan kurumların (Emniyet, Jandarma, Sahil Güvenlik) FETÖ ve benzeri oluşumlardan arındırılması gibi problemlerin ortadan kaldırılması ve tüm ilgili problemlerin gelecekte tekrar yaşanmaması adına iç güvenlik sisteminin yeni bir model ile yapılanması gereği bir zorunluluk olarak karşımıza çıkmaktadır.

İçişleri Bakanlığı’nın Kaçakçılık İstihbarat Harekat ve Bilgi Toplama Başkanlığı, Göz İdaresi Genel Müdürlügü, Afet ve Acil Durum Yönetimi Başkanlığı, İç Güvenlik Stratejileri Dairesi Başkanlığı, Mülki İdare Hizmetleri, Nüfus ve Vatandaşlık İşleri, Sivil Toplumla İlişkiler ve Güvenlik Hizmetleri (Emniyet, Jandarma, Sahil Güvenlik) gibi hizmetlerbakanlığın tüm merkez ve taşra teşkilatlarının yoğun ve koordinasyonu zor bir yapıya bürünmesine neden olmaktadır. Yukarıda sayılan iç güvenlik sistemindeki sorunların ortaya çıkmasına neden olan temel faktörün İçişleri Bakanlığı’nın yapısından kaynaklandığı anlaşılmaktadır. Bu anlamda Jandarma Genel Komutanlığı'nın ve Sahil Güvenlik Komutanlığı’nın İçişleri Bakanlığı'na bağlanması iç güvenlik sistemindeki koordinasyonun sağlanmasını ve kimlik karmaşasının önüne geçmeyi hedefleyen bir adım olarak görülse de İçişleri bakanlığının teşkilat yapısı göz önüne alındığında sağlıklı bir yapının ortaya konulmasının zorlukları görülmektedir.

Bu noktada yeni kurulacak bir İç Güvenlik Bakanlığı ile Güvenlik Hizmetleri (Emniyet, Jandarma, Sahil Güvenlik) tek çatı altında toplanabilecek ve buna bağlı olarak koordinasyon ve istihbarat sorunu aşılabilecektir.Bununla birlikte İç Güvenlik Bakanlığı'na bağlı Kaçakçılık İstihbarat Harekat ve Bilgi Toplama Dairesi Başkanlığı, Emniyet Genel Müdürlüğü (JGK, EGM, SGK), İç Güvenlik Stratejileri Dairesi Başkanlığı ve ulaşımın (kara, hava, deniz) iç güvenliği ilgilendiren boyutları da düşünülürse yeni bir daire başkanlığı olacak olan Ulaşım Güvenliği Daire Başkanlığı gibi hizmet birimleri ile iç güvenliğin idari yapısı yeniden şekillenmiş olacak olup bu yolla iç güvenlik hizmetlerinin etkinliğinin ve verimliliğinin artırılacağ 1 düşünülmektedir. Bu noktada yeni bir daire başkanlığı olarak tahsis edilecek olan Ulaşım Güvenliği Daire Başkanlığı'nıntüm ulaşım birimlerinin koordine müdürlükleri ile birlikte güçlü bir yapıda olacağı gibi ilgili daire başkanlığının faaliyetleri ileterör örgütlerine her türlü destek sağlayan kişilerin, yapıların ya da terör örgütü üyelerinin veya sempatizanlarının izlenmesi, takip edilmesi hususlarında hızlı ve etkinbir mücadele ortaya konulmuş olacaktır. Diğer yandan havalimanlarının havayolu endüstrisinin fiziksel altyapısını oluşturan önemli bir bileşen olarak yüzlerce uçağa ve milyonlarca insana barınak, hizmet ve güvenlik sağladığı düşünülürse buralarda da ortaya konan güvenlik hizmetlerinin Ulaşım Güvenliği Daire Başkanlığı ve Emniyet Genel Müdürlüğü koordinasyonu ile Emniyet Genel Müdürlüğü altında oluşturulacak hava polisi gibi uzman bir birim sayesinde tek elden yönetiminin terör örgütlerinin ortaya koyabileceği terör eylemlerinin önlenmesi bakımından etkili olacağ düşünülmektedir.

Bir sonraki görülecek adım jandarma ve polis teşkilatlanmalarının eğitim ve istihbarat paylaşımı hususlarında da ortak bir çerçeve altında toplanmalarının getireceği faydalar ve yönetim kolaylığı olacaktır. 668 sayılı olağanüstü hal kararnamesi ile Jandarma Genel Komutanlığı'nın ve Sahil Güvenlik Komutanlığı'nın İçişleri Bakanlığı'na bağlanması bu 
anlamda Emniyet, Jandarma ve Sahil Güvenlik gibi güvenlik birimlerinin tek elden yönetimini beraberinde getirecek olup eğitim noktasında ortak çerçeve oluşturacak ve bununla birlikte istihbarat paylaşımında ise hızlı ve etkin bir yapıya kavuşacaktır. Diğer yandan 694 sayılı KHK ile Milli İstihbarat Teşkilatı’nın da Cumhurbaşkanına bağlanması iç ve dış güvenliğe ilişkin istihbarat paylaşımının tek elden yönetilmesi bakımından önemli bir adım olmasının yanı sıra bakanlıklarla diğer kamu kurum ve kuruluşlarının, belirtilen görev ve yükümlülüklerinin yerine getirilmesiyle ilgili koordinasyonu sağlamak ve istihbarat çalışmalarının yönetilmesinde temel görüssleri oluşturmak ve uygulamayı belirlemek üzere, Cumhurbaşkanının başkanlığında Milli İstihbarat Koordinasyon Kurulu (MİKK) da kurulmuştur.

İçüvenlik yönetiminde yeniden yapılanmayı gerektiren yukarıdan sayılan nedenlerin yanı sıra "teknolojik gelişmeler, toplumun sosyo-ekonomik ve politik olarak yapısal değişikliğe uğraması, nüfus hareketleri, suç ve suçluların mahiyet olarak değişmesi, polisin görevlerinin tür ve özellik olarak değişmesi, çeşitli nedenlerle polisin etkinlik ve verimliliğinin düşmesi, halkın polisten beklentilerinin değişmesi ve son olarak polisin genel politikalarındaki değişim” gibi gelişmelerin de iç güvenlik sisteminde yeniden yapılanma adına birer neden olarak sayılabileceği ifade edilmektedir (Aydın, 1997, s. 5).

Sonuç olarak ülkemizde Cumhurbaşkanlığı sistemine geçiş ile birlikte tüm güvenlik ve istihbarat birimlerinin Cumhurbaşkanına bağlı olması ve bunun yanında bu çalışmada da belirtildiği üzere İç Güvenlik Bakanlığı ve ona bağlı kuruluşların teşkil edilmesi ülkemizin iç güvenlik yapısının çağa uygun hale gelmesinin önünü açacak adımlar olarak görülmektedir.Türkiye'nin iç ve dış güvenliğine yönelik hali hazırda devam eden tehditler ortadayken güvenlik birimlerine ilişkin tüm bu dönüşümün, değişim ve yeniden yapılanmanın ne kadar elzem ve acil bir durum olduğu da kaçınılmaz bir gerçeklik olarak ortaya çıkmaktadır. Yeni Türkiye ancak ve ancak 15 Temmuz hain darbe girişiminin milletçe bertaraf edilmesinin ardından başlayan bir "demokrasi hikayesi” ile amaçlarına ulaşabilecektir.

\section{Kaynakça}

Akar, E., Özer, A. ve Demirci, B. (2005). Federal Almanya Polis Teşkilatı. Polis Bilimleri Dergisi. 7(2), 69-99.

Akyüz, B. (2015). Türkiye'de İç Güvenlik Algısının Değiştirilmesi: İç Güvenlik Teşkilatı'na Yönelik Yeni Yapılanma Modeli. Savunma Bilimleri Dergisi. 14(1), 65-87.

Aydın, A. H. (1997). 21. Yüzyıla Doğru Türk Polisinin Organizasyon Yapısı ve Yönetim Sisteminde Postmodern Değişim. 21. Yüzyılda Nasıl Bir Kamu Yönetimi Sempozyumu; Güvenlik Yönetimi Grubu Bildirileri. Ankara: TODAİE. 
Bayley, D. H. (1992). State of the Art in Community Policing: An International Perspective. Vernon, J. ve McKillop, S. (Ed.), The Police and The Community: Proceedings of a Conference, Canberra: Australian Institute of Criminology. http, s.//www.aic.gov.au/media_library/publications/proceedings/05/bayley.pdf

Bellavita, C. (2008). Changing Homeland Security: What Is Homeland Security?. Homeland Security Affairs. 4(2), 1-30.

Booth, K. (1991). Security and Emancipation. Review of International Studies. 17(4), 313-326.

Booth, K. (2007). Dünya Güvenliği Kuramı. Çağdaş Üngör (Çev.). İstanbul: Vefa.

Brauch, H. G. (2003). Security and Environment Linkages on the Mediterranean Space. Brauch, H. G., Liotta, H. P., Marquina, A., Rogers, F. P. ve Selim, M. E. (Ed.), Three Phases of Research on Human and Environmental Security and Peace. New York: SpringerVerlag.

Brauch, H. G. (2008). Güvenliğin Yeniden Kavramsallaştırılması: Barış, Güvenlik, Kalkınma ve Çevre Kavramsal Dörtlüsü. Uluslararası İlişkiler Dergisi. 5(18), 1-47.

Buzan, B. (1983). People, States, and Fear The National Security Problem in International Relations. Sussex: Wheatsheaf Books Ltd.

Cabric, M. (2015). Corporate Security Management Challenges, Risks, and Strategies. Massachusetts: Elsevier Inc.

Caudle, S. L. (2009). National Security Strategies: Security from What, for Whom, and by What Means. Journal of Homeland Security and Emergency Management. 6(1), 1-28.

Crenshaw, M. (2000), The Psychology of Terrorism: An Agenda for the 21st Century. Political Psychology. 21(2), 405-420. https://www.jstor.org/stable/pdf/3791798.pdf?refreqid=excelsior\%3A5cc0b0b8c66587 02964c6eb06799b61c

Onuncu Kalkınma Planı. (2013). Cumhurbaşkanlığı Strateji ve Bütçe Başkanlığı. Ankara. http://www.sbb.gov.tr/wp-content/uploads/2018/11/Onuncu-Kalk\%C4\%B1nmaPlan\%C4\%B1-2014-2018.pdf

Çalık, Z. (2014). Yeni Güvenlik Kavramı. Çomak, H. ve Kutlu, A. G. (Ed.), Uluslararası Güvenlik Kongresi, Kocaeli: Kocaeli Üniversitesi.

Çevik, H. H., Özer, M. M., Gökçek, C. ve Hacıfazlıŏlu, T. (2005). Belçika Polis Teşkilatı: Kuvvetten Hizmete Bir Dönüşüm ve Değişim Program1. Polis Bilimleri Dergisi. 7(2), 101-118.

Çınar, B. (1997). Devlet Güvenliği, Istihbarat ve Terör. Ankara: SAM.

Çıtak, E. (2014). Yeni Gerçekçilik ve Güvenlik. Emre Ç. ve Osman Ş. (Ed.), Uluslararası İlişkilerde Güvenlik Teorik Değerlendirmeler. İstanbul: Röle Akademik. 
Çinar, Ş. (2014). Kamu Düzeninin Sağlanmasında İç Güvenlik İstihbaratının Önemi. (Yayınlanmamış Yüksek Lisans Tezi). İstanbul Üniversitesi Sosyal Bilimler Enstitüsü, İstanbul.

Demir, T. S. ve Çağlar, İ. (2017). Fetö’nün ve 15 Temmuz Darbe Girişiminin İletişim Stratejisi. Ankara: (SETA) Siyaset, Ekonomi ve Toplum Araştırmaları Vakfı.

Demirkol, C. İ. ve Nalla, M. K. (2017). Sustaining Police Officers' Motivation In Aviation Security. Journal of Transportation Security. 10(3-4), 171-187.

Doğan, F. (2010). Polis ve Jandarma Teşkilatları Açısından İç Güvenlik Yönetimi, Sorunları ve Değişimi. (Yayınlanmamış Yüksek Lisans Tezi). Ankara Üniversitesi Sosyal Bilimler Enstitüsü, Ankara.

Doğutaş, C., Dolu, O. ve Gül, S. K. (2007). A Comparative Study of the Police Training in the United Kingdom, The United States and Turkey. Polis Bilimleri Dergisi. 9(1-4), 1-20.

DPT (Devlet Planlama Teşkilatı). (2007). Adalet Hizmetleri ve Güvenlik Özel İhtisas Komisyonu Raporu, Dokuzuncu Beş Yıllık Kalkınma Planı. Ankara: Devlet Planlama Teşkilatı, Yayın No: DPT 2733.

Erdoğan, İ. (2013). Küreselleşme Olgusu Bağlamında Yeni Güvenlik Algısı. Akademik Bakış. 6(12), 265-292.

Gözler, K. (2009). İdare Hukuku. Bursa: Ekin.

Gülener, S. (2017). Devletin FETÖ'den Arındırılmasında Gelinen Aşama. https, s.//www.setav.org/devletin-fetoden-arindirilmasinda-gelinen-asama/

Gülener, S. ve Öztürk, S. Hüseyin. (2018). İtiraflarda FETÖ’nün Devlete Sızması (Askeri, Mülkiye, Adliye). https://setav.org/assets/uploads/2018/07/118.-Rapor-tamrapor.pdf

Günday, M. (1997). İdare Hukuku. Ankara: İmaj.

Karaman, Ö. (2006). Demokratik Ülkelerde Polis ve Jandarma Temel Eğitimi: Türkiye Örneği. Polis Bilimleri Dergisi. 8(2), 1-20.

Karatepe, S. (2016). Iç Güvenlik Hizmeti Veren Kolluk Kuvvetlerinin Karşılaştığı Kültürel Etkilere Dayalı Illetişim Engelleri. (Yayınlanmamış Yüksek Lisans Tezi). Avrasya Üniversitesi Sosyal Bilimler Enstitüsü, Trabzon.

Köksal, C. (2014). Türkiye’nin İ̧ Güvenlik Yönetiminde Valilerin Görev, Yetki ve Sorumluluklarının Etkinlik Açısından Değerlendirilmesi. (Yayınlanmamış Doktora Tezi). Polis Akademisi Güvenlik Bilimleri Enstitüsü, Ankara.

Mil, H. İ. (2014). Türkiye'de İç Güvenlik Teşkilatları ve Özellikleri. Süleyman Demirel Üniversitesi Vizyoner Dergisi. 5(11), 40-61.

Odyakmaz, Z., Kaymak, Ü. ve Ercan, İ. (2008). Anayasa Hukuku İdare Hukuku. İstanbul: İkinci Sayfa. 
Öksüz, H. (2006). Yeni Kamu Yönetimi Anlayışının Hesap verebilirlik Bağlamında İç Güvenlik Yönetimine Yansımaları. (Yayınlanmamış Yüksek Lisans Tezi). Cumhuriyet Üniversitesi Sosyal Bilimler Enstitüsü, Sivas.

Özer, M. M. (2006). Arjantin Kolluk Teşkilatı. Polis Bilimleri Dergisi. 8(3-4), 99-112.

Rothschild, E. (2007). What is Security. Buzan, Barry ve Hansen, Lene (Ed.), London: Sage.

Sauter, A. M. ve Carafano, J. J. (2005). Homeland Security: A Complete Guide to Understanding, Preventing, and Surviving Terrorism. New York: McGraw-Hill.

Seiple, C. (2002). The New Protracted Conflict: Homeland Security Concepts and Strategy. Orbis. 46(2), 259-273.

South African Police Service (SAPS). (2015). Annual Report 2015/16, Vote: 23, https, s.//www.saps.gov.za/about/stratframework/annual_report/2015_2016/saps_annual_rep ort_2015_2016.pdf

Sözen, S. (2003). Kolluğun Görev ve Yetkilerine Genel Bir Bakış. Özgür, Aydın Ziya (Ed.), Jandarmanın Görev ve Yetkileri. Eskişehir: Anadolu Üniversitesi.

Şimşek, Y. ve Köseli, M. (2007). Finlandiya Polis Teşkilatı. Polis Bilimleri Dergisi. 9(1-4), 133-150.

Şöhret, M. (2014). Kopenhag ve Aberystwyth Ekolleri Çerçevesinde 21. Yüzyılda Güvenliğin Değişen Kapsamı ve Boyutu. Çomak, Hasret ve Kutlu, Ayşegül Gökalp (Ed.), Uluslararası Güvenlik Kongresi, 638-645. Kocaeli: Kocaeli Üniversitesi.

Türkiye Barolar Birliği. (2006). Türkiye ve Terörizm. Ankara: Türkiye Barolar Birliği.

Ulutaş, U. (2016). 5 Soru: Rus Büyükelçi Karlov’a Düzenlenen Suikast. https, s.//www.setav.org/5-soru-rus-buyukelci-karlova-duzenlenen-suikast/

Uzun, C. D., Akgün, M. H. ve Yücel, H. (2017). İddianamelerde 15 Temmuz Darbe Girişimi ve Fetö. Ankara: (SETA) Siyaset, Ekonomi ve Toplum Araştırmaları Vakfı.

Üzel, M. F. (2008). Türkiye'de İç Güvenlik Teşkilatlarının Yeniden Yapılandırılması. (Yayınlanmamış Yüksek Lisans Tezi). Mersin Üniversitesi Sosyal Bilimler Enstitüsü, Mersin.

Waever, O. (2012). Security. Encyclopedia of Global Studies içinde (C. 4). Thousand Oaks, Calif: Sage.

Waever, O. (2014). Cooperative Security A New Concept?. Flockhart, Trine (Ed.), DIIS Report 2014: 01. Copenhagen: Danish Institute For International Studies.

Yılmaz, S. (2011). 11 Eylül Sonrasında ABD ve Türkiye'deki İç Güvenlik Yeniden Yapılanmalarının Karşılaştırması. Ç.Ü. Sosyal Bilimler Enstitüsü Dergisi. 20(3), 361380. 
Yılmaz, S. (2011a). Türkiye'deki İç Güvenlik Yapılanmasında Değişim İhtiyacı ve Güvenlik Yöneticilerinin Değişime Yönelik Tutum Ve Davranışları Üzerine Bir Araştırma. (Yayınlanmamış Doktora Tezi). Çukurova Üniversitesi Sosyal Bilimler Enstitüsü, Adana.

Yılmaz, S. (2011b). 11 Eylül Sonrasında ABD Ve Türkiye'deki İç Güvenlik Yeniden Yapılanmalarının Karşılaştırması. Ç.Ü. Sosyal Bilimler Enstitüsü Dergisi. 20 (3), 361380 .

Y1lmaz, S. (2012). Terörle Mücadelede Yeni İç Güvenlik Yönetimi. Ankara: Detay.

Yilmaz, S. (2013). Public Trust in the Homeland Security System: A Study on Public Perceptions of Combating Terrorism in Turkey. Uluslararası Alanya Issletme Fakültesi Dergisi. 5(2), 119-128.

Zengin, M. G. (2014). Türkiye'de İç Güvenlik Yapılanması ve Kamu Düzeni ve Güvenliği Müsteşarlığı. (Yayınlanmamış Doktora Tezi). Gaziantep Üniversitesi Sosyal Bilimler Enstitüsü, Ankara.

\section{Internet Kaynakları}

http, s.//www.tdk.gov.tr (Erişim Tarihleri, s. Ekim - Aralık 2016). 